\title{
COMPULSORY "HOSPITAL-ACCIDENT" \\ INSURANCE: A NEEDED FIRST STEP \\ TOWARD THE DISPLACEMENT \\ OF LIABILITY FOR "MEDICAL MALPRACTICE"
}

\author{
Albert A. Ehrenzweig†
}

B OTH the patient and those entrusted with his care are poorly served by present rules and institutions relating to liability for medical malpractice. This is generally known and said. On the one hand, the physician, the nurse, the anesthetist, the hospital administrator and others who, in the chain process of modern medicine, in easy retrospect, appear to have committed an error of judgment or technique to the patient's detriment, may be exposed to years of emotional and financial stress or even to economic and professional disaster. Called upon to alleviate such exposure, liability insurers seeking to distribute incalculable risks, find themselves compelled to charge more or less arbitrary premiums which result in a disproportionate burden on the insured and ultimately on the public. On the other hand, the patient who seeks indemnity for an injury that he suffered somewhere in the chain process of modern medicine, sees himself compelled to assert and to prove unprovable fault. The complexity and uncertainty of the resulting litigation must cause disproportionate expense. Moreover, there is the ever growing clamor of plaintiffs' attorneys who chide the medical profession for discouraging its members from assisting plaintiffs in a "conspiracy of silence." 1 Finally, even the patient who has been successful in obtaining a judgment may remain without compensation where the defendant is insolvent and fails to carry liability insurance.

Many of these problems are common to other kinds of enterprise liability and have begun to occupy legislators and scholars particularly in that area which most obviously and dramatically requires reform, the law of automobile liability. I have tried elsewhere to show that the ultimate solution in that area calls for replacing our present system of tort liability and tort insurance by a compulsory accident insurance

† Walter Perry Johnson Professor of Law, University of California, Berkeley.

I See, e.g., Belli, Ready for the Plaintiff, 30 TEMr. L.Q. 408 (1957). For a more balanced view and additional references, see Polsky, The Malpractice Dilemma: $A$ Cure for Frustration, 30 TEMP. L.Q. 359 (1957). See also Caswell, $A$ Surgeon's Thoughts on Malpractice, 30 TEMP. L.Q. 391 (1957). 
for third party benefit. ${ }^{2}$ Though fundamental reforms of this kind will probably be late in coming because of the lack of organized groups of proponents (pedestrian victims of the motorist), the powerful organizations of physicians and hospitals which now suffer the impact of a similar obsolete and in many respects vicious law, should be able to bring about sooner the needed change and thus to create the model for analogous solutions in other fields.

The enterprise character of modern medicine is most clearly decisive for indemnity claims based on the vicarious liability of hospitals. Here, in contrast to claims against the alleged individual injurer himself, the law's primary concern is the equitable distribution of losses unavoidably caused by mass operations and is undisturbed by the inclination of the judge and jury to protect the defendant's professional standing. ${ }^{3}$ It is for this reason that the attempt will be made in the present study to approach the general problem of "malpractice" liability and insurance within the limited area of the vicarious liability of hospitals.

The first reported cases which held hospitals liable for injuries caused to their patients were related to private institutions and were decided at the turn of the nineteenth century when such institutions began to play a significant role. ${ }^{4}$ Until then most if not all hospitals had been operated by either charities or governmental agencies which were protected against all liability by the then generally prevailing doctrines of governmental and charitable immunity. ${ }^{5}$ But the new development

2 Ehrenzweig, "Full Aid" Insurance for the Traffic Victim (1954). On the basis of my proposal, a similar plan has been developed to replace the present chaos of products liability. Feldman, Liability of Manufacturers of Home Furnishings for Harm Done by the Product, 1955 INs. L.J. 519. See also for air accidents, Sand, Limitation of Liability and Passengers" Accident Compensation under the Warsaw Convention, 11 AM. J. Сомp. L. 21, 43-5I (1962).

3 See Fleming, Developments in the English Law of Medical Liability, 12 VAND. $I$. REV. 633, 634 (1959). Other typical situations involving vicarious liability concern medical partnerships, joint enterprises and other arrangements involving multiple physicians. See, e.g., Gerhardt v. Fresno Medical Group, 217 Cal. App. 2d 394, 31 Cal. Rptr. 633 (1963). For further instances and in general, see Louiseld \& WiLliaMs, Trial of MaLPRactice Cases \$§ 16.01-.08 (1960) [hereinafter cited as Louisell \& Wirliams].

4 See, e.g., Union Pac. Ry. v. Artist, 60 Fed. 365 (8th Cir. 1894) (contract theory, see Louisell \& WrLliams $\$ 18.14$ ); Brown v. Société Française de Bienfaisance Mutuelle, 138 Cal. 475, 71 Pac. 516 (1903); Hogan v. Clarksburg Hosp. Co., 63 W. Va. 84, 59 S.E. 943 (1907); Drefahl v. Connell, 85 Wis. 109, 55 N.W. 160 (1893); see generally, 30 C.J. 465 (1923).

5 See Callender, Torts of Hospitals, 15 Am. L. Rev. 640 (1881); 13 R.C.L. Hospitals $\$ 13$ (1916); and generally Hospital Law Manual, Atrorney's Volume, Negligence II, III (1959); Lovisell \& WrLLIAMs \$\$ 17.01-.57; Holdridge, Tort Liability of Hospitals, 8 GLEv-MAR. L. REv. 394, 407-15 (1959); Levin, Malpractice and the Federal Tort Claims Act, 1963 INs. L.J. 453; Lipson, Charitable Immunity: The Plague of Modern Tort Concepts, 7 Clev.-MAR. L. Rev. 483 (1958). See also Sandor, The History of Professional Liability Suits in the United States, 163 A.M.A.J. 459 (1957). On the 
was from its beginning affected by what may be called the original sin of our law of enterprise liability. Here, as in other fields, a rapidly growing new industry lacked an appropriate legal vehicle for the distribution of the losses caused by its hazardous mass operations. The law of negligence was and has since been used and abused to fill a gap that had been created too suddenly to permit legislative action.

Elsewhere I have tried to show how this original sin of enterprise liability has led to an over-broadening of traditional tort concepts in a new law of "negligence without fault,"6 and how liability insurance, though threatening the purpose of tort liability as an admonitory device for the promotion of care, and though poorly adapted for its new function as a device for the distribution of unavoidable losses, has come to be used to make the new non-fault liability bearable for the entrepreneur. These observations are not only fully applicable to the liability and liability insurance of private hospitals but, in view of the progressing breakdown of the immunity doctrine, ${ }^{7}$ to an increasing extent to governmental and charitable hospitals as well. Here, as in the law of enterprise liability in general, current practice gives the claimant both too little and too much, and thus fails both him and the entrepreneur.

\section{Too Little and Too Mugh}

To impose vicarious liability on a hospital for the negligence of its employees without regard to any fault of its own in their selection or supervision can, like most other types of vicarious liability, be justified by the law's concern for the "victim's" protection. But once the hospital's non-fault liability is thus justified as a means to avoid discrimination between patients negligently injured by well-to-do and by judgmentproof employees, there is no conceivable reason why such liability should not also be imposed to avoid discrimination between those patients injured accidentally and those injured by an employee's negligence. In fact, courts and juries have found many ways to eliminate or mitigate this discrimination. Most important in this respect is perhaps the broad application of the doctrine of res ipsa loquitur ${ }^{8}$ which has been used to

history of hospitals in general, see Risley, House of Healing: The Story of the Hosprtal (1961).

6 See Ehrenzweig, Negligence Wrthout Fault (1951).

7 See, e.g., Muskopf v. Corning Hosp. Dist., 55 Cal. 2d 211, 359 P.2d 457 (1961). For a collection of authorities, see Hospital Law Mandal, Atrorney's Volume (1959); Louisell \& Williass \$ 16.07. The non-legal literature is enormous. See headings on Liability and Insurance in Hospital Literature Index. Only the most recent publications have been referred to in this paper.

8 See Long, The Physician and the Law 23-28 (1959); Louisell \& Williams $\$ \S$ 14.01-15.08; Holdridge, supra note 5, at 403. That the physician's "negligence" liability is typically not considered one for true fault appears, for instance, in the fact that 
relieve the patient not only of his duty to prove "negligence" but even of his duty to identify a "negligent" employee. ${ }^{9}$ But by thus correcting the too little of our tort laws, courts have given too much, to the detriment of the community of risk, by imposing, without regard to fault, an unlimited liability which can be justified only as a means for the atonement of wrongs.

The courts have reacted in a similar manner to the remaining discrimination between those injured by one "employed" by the hospital, and those injured by one otherwise a part of the hospital organization.10 Hospital liability from its inception has been severely limited by the tests generally applicable to vicarious liability. Thus this liability has been frequently denied for injuries inflicted by physicians and their own employees, either because such physicians have been treated as independent contractors, 11 or because their "professional" services have been considered beyond the control of the hospital employer. This limitation of the hospital's liability has even been extended to hospital employees lent to the physician and to personnel paid by the patient himself.12 But again, having given too little so long, courts now tend to go to the other extreme. To an increasing extent they have treated the hospital and its operations as a unitary enterprise ${ }^{13}$ all of whose hazards are most effectively distributed through the hospital's liability and liability insurance. Thus the distinction between administrative and professional services is about to be wholly abandoned;14 hospital employees "Ient" to the physician are treated as employees of both the hospital15

this so-called negligence is not treated as an intervening cause in dealing with claims against the primary injurer. See Prosser, Torts 273 (2d ed. 1955).

9 Ybarra v. Spangard, 25 Cal. 2d 486, 154 P.2d 687 (1944); Frost v. Des Moines Still College of Osteopathy and Surgery, 248 Iowa 294, 79 N.W.2d 306 (1956); Loursert \&: WiLriams § 14.07; Fleming, supra note 3, at 646-48.

10 See generally Fleming, Torts 328-30 (2d ed. 1961); Fleming, supra note 3, at 637.

11 See, e.g., Moon v. Mercy Hosp., 373 P.2d 944 (Colo. 1962). See generally Annot., 69 A.L.R.2d 305 (1960).

12 See, e.g., Ware v. Culp, 24 Cal. App. 2d 22, 74 P.2d 283 (1937) (nurse); Minogue v. Rutland Hosp., 119 Vt. 336, 125 A.2d 796 (1956) (nurse).

13 See note 9 supra, and generally Louisell \& WilLIAMs \$ 16.07; Fleming, supra note 3, at 637-38; Miller, Malpractice Used as a Hospital Defense, 10 CLEv.-MAR. L. REv. 1 (1961). For the parallel development in France where the hospital's only defense is causation by foreign cause, see 1 Mazeaud \& Tunc, Responsaburté Civile \& 159-2 (5th ed. 1957); Crépeau, La Responsabilité civile des Médecins et de l'Établissement hospitalier (diss. Paris 1955).

14 Bing v. Thunig, 2 N.Y.2d 656, 143 N.E.2d 3 (1957). See generally HosprTal Law Manual, Atrorney's Volume, Negligence $I$ \$ $\$$-5 (1959); Kramer, Medical MaLPRACTICE 17-22 (1962); Holdridge, supra note 5, at 404-07; Miller, supra note 13.

15 See Dickerson v. American Sugar Ref. Co., 211 F.2d 200 (3d Cir. 1954). See generally Hospital Law Manual, Atrorney's Volume, Negligence I \$ 3-1 (1959); Louisell \& WiLLIAMs \$ 16.05 . 
and that physician and even concessionaires have been held to be employees of the hospital for the purpose of holding it liable.16

The resulting unlimited liability of hospitals for nearly all mishaps occurring in their operation would have proved intolerable, both economically and psychologically, had it not been for the availability of liability insurance. ${ }^{17}$ But that institution, while relieving the most severe symptoms of the disease, has, for the following reasons, failed to cure it.

1. There remains the great burden on time, energy and peace of mind that is imposed on potential defendants by the continuous threat of strike suits by claim-prone patients and by the possibility of jury verdicts in excess of available or economically feasible insurance coverage. In the face of these threats both physicians and hospitals are likely to become increasingly wary of fruitful experimentation and hazardous treatments.

2. The present possibility of suits against several persons for the same incident compel each of such persons (including the hospital, the nurse ${ }^{18}$ and the physician) to carry his own liability insurance and thus to increase the over-all premium load to the disadvantage of the public as the ultimate consumer.

3. The wastefulness of multiple liabilities and premiums also appears in the redistribution by subrogation claims among liability insurers, of losses already distributed.

4. Since liability insurance is not compulsory, even the most valid claim may remain unsatisfied if the defendant is insolvent.

5. Since liability coverage usually excludes liability for criminal acts and acts performed in the state of intoxication or under the influence of drugs, and since the policy will usually contain conditions concerning

16 E.g., Carroll v. Richardson, 201 Va. 157, 110 S.E.2d 193 (1959) (defendant pathologist had contract to perform all laboratory and pathological services for lessor hospital). On the hospital's liability for acts of its auxiliaries, see Hosprtal Law Manual, AtroRneY's Volume, Hospital Auxiliaries \$ 3-2 (1959).

17 Significantly, the judicial abolition of the immunity doctrine induced at least one legislature temporarily to restore that immunity for amounts exceeding $\$ 10,000$ so as to enable the hospitals to protect themselves by liability insurance. N.J. STAT. ANN. tit. $2 A$, §§ 53A-7, 8 (1962). See Anasiewicz v. Sacred Heart Church, 74 N.J. Super. 532, 181 A.2d 787, cert. denied, 38 N.J. 305, 184 A.2d 419 (1962); Johnston, Limited Liability for Hospitals, Hosp. Mgt., Jan. 1959, p. 28. The New Jersey solution has been acclaimed as a "fair compromise." Southwick, Current Legal Trends in Hospital Liability, Hospitals, Feb. 1962, pp. 42, 120. See also LouisenL \& WILLIAMs \$ 20.01; Hirsh, Insuring Against Medical Professional Liability, 12 VAND. L. REv. 667 (1959). Pre-treatment releases from liability obviously do not offer the needed relief. See, e.g., Tunkl v. Regents of the University of California, 32 Cal. Rptr. 33, 383 P.2d 441 (1963), invalidating such a release as a matter of law.

18 See Note, Malpractice Liability Policy Needed by Practical Nurses, 8 PrAc. Nurs. 6 (1958). 
settlement and cooperation, ${ }^{19}$ the patient may remain uncompensated even if the defendant carries insurance.

6. Finally, and perhaps most important, in many cases such recovery as is ultimately obtained by the patient, must be paid for with the strain and expense of protracted litigation.

\section{The Proposed Scheme}

A new scheme must be designed to indemnify the patient for losses caused by the hazards of modern mass enterprise without requiring him to find and to prove a real or fictitious fault, without forcing him into litigation with its attendant delay, expense and perjury, and without imposing on him the risk of the collectibility of his claim. Such a scheme must at the same time protect the hospital against unlimited liability for losses unavoidably caused in its mass operation, and must protect the hospital's employees and contractors against the paralyzing risk of ruinous demands. Finally, such a scheme must spare both the patient and the hospital the disproportionate and idle expense of multiple liability insurance and the confusion of a tort law that was never designed for and is therefore unable to effect the equitable distribution of unavoidable risk. If all this is to be achieved, tort law, the villain of the piece, must go, and so must tort insurance, its accomplice. Both must be replaced by a system of compulsory "accident" insurance for the patient's benefit. While the settlement of many details would require a careful factual and functional inquiry, the outline of such a system can now be developed.

1. Every hospital, as a condition of its license to operate, would have to carry minimum "hospital-accident insurance" for the benefit of its patients. Additional coverage of the same type would be made available to every patient on an optional basis.

2. This insurance would enable the patient injured by a "hospitalaccident," i.e., a failure in the process of his treatment relating to services which were rendered or should have been rendered, ${ }^{20}$ or, in case of death,

19 See Hirsh, supra note 17 , at 669 . For suggested limitations of this exclusion, see $i d$. at 677. See also Loursell \& Williams $\$ 20.04$; Note, Goverage and Exclusions of Professional Liability Insurance, 170 A.M.A.J. 813 (1959).

20 The term "hospital-accident" as here proposed is, of course, not in accord with current definitions of "accident." "Hospital-health" insurance, in a terminology following the progressing replacement of the term "accident" in general "health insurance," would have been preferable but would have been ambiguous as possibly referring to hospital insurance as now written. But the new "hospital-accident" insurance could well be written so as also to cover all accidents in the accepted sense of the word. It has been estimated that such accidents happen to $3.46 \%$ of all patients. Stone, What Is a Reasonable "Standard Rate" for Patient Accidents?, Hospitals, Oct. 1962, p. 43. The following discussion follows my outline of an automobile insurance 
that patient's representative, to claim the benefits of the policy without having to identify any specific injurer or a causative "negligence," and without having to take into account the benefits derived from other (life, health, hospital or social) insurance other than those covering cash expenses.

3. Such "hospital-accident insurance" would be written largely on the model of existing accident or health insurance policies.

4. Any patient unable to recover on such a policy for his "hospitalaccident," e.g., because of the hospital's failure to keep its coverage in force, would be entitled to an equivalent indemnity from an Uncompensated-Injury Fund to be organized and operated by all hospital accident insurers of the state.

5. Any hospital carrying the prescribed minimum coverage, as well as all its employees and independent contractors, would be relieved of their common-law liability for ordinary (in contrast to criminal) negligence, and of all vicarious liability.

6. Liability for harm caused intentionally or by criminal negligence could, upon the patient's request or ex officio, only be claimed from the defendant by the Uncompensated-Injury Fund which would divide the proceeds between itself and the patient in a manner to be prescribed by statute. Being intended as a mere supplement to the patient's minimum protection, such recoveries would, as "tort fines," in keeping with their primarily punitive character, be measured by the gravity of the offense and the defendant's financial circumstances. No insurance would be available against such liability for criminal negligence.

7. If recovery for an intentional tort or criminal negligence should fail because of the defendant's absence or insolvency, the patient would obtain a statutory amount from the Uncompensated-Injury Fund.

\section{How It Would Operate}

The proposed scheme, if implemented as suggested below, would offer many advantages over the scheme of tort liability and tort insurance now in effect.

\section{Assurance and Easy Determination of Equal Minimum Awards}

The patient would be assured a minimum recovery for any injury to his health that he might sustain for reasons other than those induced by his illness, during his stay at the hospital. Such recovery would be equally assured in cases of criminal acts or other cases coverage of which is excluded from current malpractice insurance policies.

scheme in EHRENZwEIG, op. cit. supra note 2, at 32-38. See also Ehrenzweig, Towards an Automobile Compensation Plan, 11 FED. INs. Couns. Q. 5 (1961). 
Accident insurance policies (whose pattern has remained substantially unchanged through the last century) ${ }^{21}$ could furnish appropriate models in determining an optimum schedule of benefits. In that determination experiences gathered in workmen's compensation (with particular regard to the General Employees' Compensation Act, ${ }^{22}$ the benefits of which are generally recognized as adequate) would prove equally useful. The indemnity would be based on a fixed tariff as in accident insurance, rather than on actual earnings or earning power as in many systems of workmen's compensation. This tariff would be based on the minimum needs of low-income groups since it is these groups that offer the most urgent social problem. Moreover, low awards would reduce abuse and expense. As everybody is able to assess his own risk, if he considers his own "worth" in excess of the statutory award, he will be free, and indeed encouraged by hospital and physician, to take additional "hospitalaccident insurance." The proposed scheme, which would fix the potential recovery, would thus be fairer to the well-to-do patient than the present system under which the uncertainties of recovery inherent in tort liability and tort insurance make planning of protection impossible.

On the other hand, awards must be high enough so as not to force juries to find criminal negligence merely for the sake of being able to give adequate compensation, as they have done almost consistently where the statutory award is too low, e.g., under the Warsaw Convention concerning air accidents. ${ }^{23}$

The basic unit of indemnity should, as in most accident ${ }^{24}$ and workmen's compensation insurance policies, be the weekly indemnity. In order to avoid amounts either so high as to produce moral hazard and prohibitive premiums, or so low as to fall short of minimum needs, a weekly indemnity of fifty dollars would seem appropriate at this time. ${ }^{25}$ But a proviso might be added that certain sizable cost-of-living index fluctuations would automatically increase or decrease this amount as well as the corresponding premium.

21 Faulkner, Health Insurance 512-33 (1960). See also Mowbray \& Blanchard, INSURANCE $282-87$ (5th ed. 1961).

225 U.S.C. $\$ 751$ (1958).

23 See Errenzweig, op. cit. supra note 2, at 27. See generally Sand, supra note 2.

24 The relation, for "level insurance," between the principal sum (\$1,000 for death) and the weekly indemnity (\$5) has remained the same since 1864. See FAULKNER, op. cit. supra note 21 , at 517.

25 The minimum rate payable to federal employees, with certain exceptions, is $\$ 112.50$ per month. 63 Stat. 858 (1949), 5 U.S.C. $\$ 756$ (c) (1958). For an alternative benefit structure, see, e.g., Riesenfeld, Efficacy and Costs of Workmen's Compensation, 49 CALIF. L. Rev. 631 (1961) (brought up to date in Occupational Disability and Public Policy 279, 311 (Cheit \& Gordon ed. 1963)). For possible social security analogues, see Pollack, Disability Insurance Under Social Security, in Occupational Disabilitry and Public PoLicy, op. cit. supra at $158,177-82$. 
On the weekly unit basis specific benefits would be computed as follows:

In the event of death, the lump-sum payment of 200 weekly indemnities usually provided in an accident policy would fail to offer a minimum subsistence to the bereaved family. Therefore, a percentage-perhaps forty-five per cent-of the weekly indemnity should be the basic claim, until death or remarriage, of widows or widowers primarily dependent on the deceased. An additional fifteen per cent should be provided for each child until death or majority, with the limitation that the total claim on behalf of the deceased's family may not exceed seventyfive per cent of the basic indemnity. ${ }^{26} \mathrm{~A}$ lump sum of 500 dollars could be provided for funeral expenses. ${ }^{27}$ To accelerate and simplify adjustment, recipients might be given the option of requesting a Iump-sum payment of 10,000 dollars or an amount computed on the basis of existing mortality tables. Unlawful continuation of receipt should be discouraged by punishment. ${ }^{28}$

Total permanent disability would entitle the patient to the basic weekly indemnity for life. ${ }^{29} \mathrm{Here}$, as in the case of death, both the insurer and the recipient might be given an option to request a lump-sum payment, either fixed in the policy or computed on the basis of mortality rates. Loss, or loss of use, of both hands, arms, feet, legs or eyes should be considered prima facie evidence of total permanent disability, ${ }^{30}$ and, in contrast to most workmen's compensation schemes and ordinary accident insurance, objective standards should be given general preference. ${ }^{31}$

Partial disability, temporary or permanent, and temporary total disability would of course raise questions in the ascertainment of fractional or temporary claims-concededly more so than in present-day liability or accident insurance with its usual maximum benefit periods of from three to four months. ${ }^{32}$ These difficulties will have to be faced, however, if the social purpose of the proposed plan is to be safeguarded. They are, after all, being faced in workmen's compensation today. ${ }^{33}$ Arbitration

2639 Stat. 744 (1916), 5 U.S.C. $\$ 760$ (1958).

2739 Stat. 745 (1916), 5 U.S.C. \& 761 (1958).

2839 Stat. 744 (1916), 5 U.S.C. $\$ 760(L)$ (1958).

20 See FAULKNER, op. cit. supra note 21 , at 101.

3063 Stat. 855 (1949), 5 U.S.C. \& 753 (1958).

31 Concerning the "any occupation" in contrast to the "his occupation" test see FAULKNer, op. cit. supra note 21, at 102; Riesenfeld, Basic Problems in the Administration of Workmen's Compensation, 36 MrNs. L. REv. 119, 124 (1952).

32 See, e.g., FAULKNer, op. cit. supra note 21, at 111; MAcINTYRE, Voluntary Health INSURANCE AND RATE MAKING 54-64 (1962).

33 See generally, Riesenfeld, supra note 31 , at 122, 134. 
agreements in the policy ${ }^{34}$ may expedite investigation and decision. A great deal might be gained by giving both the insurer and the insured, or merely the latter, the option of lump-sum payment for certain typical injuries. Compensation could be fixed in terms of the weekly indemnity or in terms of flat amounts on the model of accident insurance ${ }^{35}$ or the Federal Employees' Compensation Act. ${ }^{36}$ In addition, surgical or attendant's care and hospitalization would be compensable in fixed percentages of the basic weekly rate, ${ }^{37}$ while modern rehabilitation provisions might help in facilitating adjustment. ${ }^{38} \mathrm{~A}$ considerable reduction of premiums, which has been estimated at twenty per cent, could be achieved by providing for a waiting period of seven days, which is said to eliminate thirty-two per cent of accident claims; ${ }^{39}$ and in contrast to the prevailing practice in accident insurance, by taking into account payments received from other sources (such as independent health or hospital insurance) for cash expenses (such as surgery) though not for loss of income ${ }^{40}$ or unmeasurable harm.

\section{Elimination of Threat, Gamble, Stigma and Expense of Litigation}

The greatest advantage of the proposed scheme would be that it would not only relieve the patient of the economic and emotional strain of protracted litigation requiring difficult or impossible proof, but would also relieve the defendant (hospital, nursing home, ${ }^{41}$ nurse, officers, and

34 For early practices to this effect in workmen's compensation, see id. at 130 . In fire insurance such agreements are the rule.

35 See, e.g., Riegel \& Miller, Insurance Principles and Practices 264 (1947): 200 weeks for one hand and one foot, hand or foot and one eye; 100 weeks for either hand or foot; 65 weeks for one eye; 50 weeks for thumb and index finger. See also Faulkner, op. cit. supra note 2 , at 106 , for similar schedules.

3663 Stat. 855 (1949), 5 U.S.C. \& 755(a) (1958): 205 weeks for one foot; 244 weeks for one hand; 160 weeks for one eye. As to workmen's compensation in general, see Riesenfeld, supra note 31 , at 125. In contrast to awards in that field, hospital compensation, being based on minimum needs rather than earning power, will have to stress objective standards and leave to excess accident insurance, see text at note 22 supra, the alleviation of any individual hardship caused by this computation.

37 See 63 Stat. 858 (1949), 5 U.S.C. \$ 756(b)(1) (1958).

38 See 63 Stat. 858 (1949), 5 U.S.C. \$ 756(d) (1958); Gulledge, Vocational Rehabilitation of Industrially Injured Workers, in Occupational Disability and Public Policy, op. cit. supra note 25, at 395; Riesenfeld, supra note 31, at 120; Somers and Somers, Rehabilitation and Workmen's Compensation, 1954 INs. L.J. 71.

39 The American Accident Table indicates that almost one-half of all industrial accidents cause disability lasting one week or less. See REEDE, ADEQUACY OF WORKMEN's Compensation 30 (1947). In 63 Stat. 854 (1949), 5 U.S.C. $\$ 752$ (1958), compensation is denied to federal employees for the first three days, unless the disability exceeds twenty-one days or is followed by permanent disability. See also FAULKNER, op. cit. supra note 21 , at $110-11$.

40 As in accident insurance, continued receipt of wages should probably not be taken into account. Experience has failed to show any increase of the moral hazard.

41 See Note, Mod. Hosp., April, 1962, p. 16. 
above all, the physician) of a continuous threat crippling both sound experimentation and courageous treatment. ${ }^{42}$

Moreover, the proposed scheme would eliminate the element of a gamble inherent in any personal injury suit which may now deter many from prosecuting just claims. Also, courts and parties would cease engaging in the game of hide-and-see $k^{43}$ now disgracing both the institution of insurance and court procedure: The insurer, instead of secretively carrying the burden and claiming the guidance of the proceedings, would take his proper place as the protector of both the public and its medical facilities. "Direct actions" against the insurer, ${ }^{44}$ now permissible in only a few states, would become a matter of course.

Under the present law the patient must prove not only causation of his injury but also the blameworthy character of such causation. The proposed scheme would reduce this burden to a duty to prove causation. To be sure, even that duty is not easily defined. Some such formula as that now often used in malpractice insurance policies, namely the reference to "services rendered or which should have been rendered," 45 would have to be retained despite its frequent ambiguity. But both the plaintiff and the defendant would be relieved of the burden and stigma of having to prove or disprove an act or omission of "malpractice."

Finally, although a definitive conclusion could be reached only after a thorough actuarial study, ${ }^{46}$ the premium cost of the proposed scheme would presumably be considerably smaller than that of the existing system of liability insurance. There would be avoided the need for multiple insurance now carried by the hospital, its employees and independent contractors, all of whom are now potentially liable for the same event. Wasteful subrogation suits, which would be limited to cases involving criminal acts, would become rare. Moreover, the dramatic reduction of litigation with its concomitant cost and fees would eliminate a burdensome element of the total expense. And, most important, the benefits accruing under the policy would be limited and definite in

42 See Lourselr \& WILliaxis \& 20.01; Morris, Medical Malpractice-A Changing Picture, 1956 Ins. L.J. 319; Silverman, Medicine's Legal Nightmare, Sat. Eve. Post, April 11, p. 13; April 18, p. 31; April 25, p. 36 (1959). The threat to physicians and other individuals is particularly great where the hospital itself remains immune. See Regan, Negligence Immunity, Hosp. Prog., July 1962, p. 27; Southwick, Current Legal Trends in Hospital Liability, Hospitals, Feb. 16, 1962, pp. 42, 117.

43 LOUisell \& WILLIAMS \& 20.02 n.23.

$44 I d$. at $\$ 20.02$, especially pp. $587-88$.

$45 I d$. at $\$ 20.03$. See text accompanying note 20 supra.

46 "[R]eported cases represent only a small fraction of suits filed and claims brought against physicians .... It is unfortunate that complete statistical data is not available from the insurance companies ...." Stetler, The History of Reported Medical Professional Liability Cases, 30 TEMP. L.Q. 366, 383 (1957). 
amount, thus rendering unnecessary the calculation of widely vacillating and often exorbitant jury assessments. ${ }^{47}$

\section{Promotion of Care and Safety; Additional Tort Recovery}

The physician, now working under the continuous threat of personal liability, would, it has been stressed before, be relieved of the concern which seriously impairs the progress and effectiveness of medical practice. This development would not, as might be suggested, reduce the prevailing standard of care, but increase it. For, like current liability insurance, the proposed scheme would not protect the physician against liability incurred by criminal negligence. And, unlike the present system, the proposed scheme would not only deprive the offender of his insurance protection, but it would assure proper civil sanctions in cases of such negligence by providing for ex officio recovery on the patient's behalf by the Uncompensated-Injury Fund. These sanctions would be fairer to the defendant in that the scheme would stipulate the imposition of "tort fines" to be measured by the gravity of the offense and the defendant's financial circumstances rather than the purely accidental extent of harm.

To be sure, such a scheme, while promoting safety, would discriminate between those injured by accident or ordinary negligence, who would be limited to statutory recovery, and those injured by criminal negligence, who would retain their tort claims. In a wholly rational world, that discrimination could be avoided by leaving the admonition of the criminal to the criminal law. But such a solution, while logically the only sound one, would fail to respond to the victim's demand for revenge which, though irrational, must be taken into account as being no less real than rational needs. 48 It is proposed, therefore, to maintain the civil action and to reduce the resulting discrimination by having the Fund retain a statutory percentage of the net recovery, which may vary from ten to fifty per cent according to the amounts involved and possibly the gravity of the crime. Failure of recovery because of the defendant's absence or insolvency would be at least partly neutralized by a contribution from the Uncompensated-Injury Fund.

\section{GoNCLUSION}

Suits for "medical malpractice" have come to endanger the functioning of medical care and legal process. While producing intolerable economic and emotional strain for all parties, they benefit no one. These

47 See Mettler and Brenner, Are Malpractice Premiums Being Set by Guesswork?, 36 Men. ECON. 241 (1959). On the rating problem generally, see MAcINTYRE, op. cit. supra note 32 , at 32 .

48 See generally, Ehrenzweig, A Psychoanalysis of Negligence, 47 Nw. U.L. REv. 855 (1953); Ehrenzweig, $A$ Psychoanalysis of the Insanity Plea, - YaLE L.J. - (1964). 
two great professions, with the imaginative help of the insurance industry, that must give us new answers. I have suggested that such answers should be sought in the replacement of tort liability and tort insurance by a new structure based on insuring the loss where it occurs. I have tried to show that we may thus achieve the assurance and easy determination of equal minimum awards, the elimination of the threat, gamble, stigma and expense of litigation, and the promotion of care and safety. Only if the law thus proves capable of responding to new needs, will it be able to save free medical enterprise from the mounting pressures of a collective society. 